\section{Design and Construction of the Penn State High Tunnel}

\author{
William J. Lamont, Jr., ${ }^{1}$ \\ Martin R. McGann, ${ }^{2}$ \\ Michael D. Orzolek, ${ }^{3}$ \\ Nymbura Mbugua, ${ }^{4}$ \\ Bruce Dye,${ }^{5}$ and \\ Dayton Reese 6
}

Additional INDEX WOrds. season extending technology, plasticulture, plastic mulch, drip irrigation, fertigation

Summary. Plasticulture technology, especially high tunnels for extending the production period of a wide variety of horticultural crops, is an accepted production practice worldwide. In particular, high tunnels offer a production system that minimizes the effect of the environment on crop production and allows growers to continue to farm in densely populated areas. Only recently has the use of high tunnels in the U.S. been investigated and this research has been centered in the northeastern U.S. In 1999 the High Tunnel Research and Education Facility was established at Pennsylvania State University that resulted in the development of a unique high tunnel design. A detailed description of the new design and construction is presented in this report.

$\mathrm{T}$ he High Tunnel Research and Education Facility (HTREF) was established at the Pennsylvania State University as part of the Penn State Center for Plasticulture. The center is a clearinghouse for research and educational efforts in the field of plasticulture, which is the use of plastics in any phase of agricul-

\footnotetext{
Department of Horticulture, Pennsylvannis State University, University Park, PA 16802.

${ }^{1}$ Associate professor of vegetale crops.

${ }^{2}$ Assistant professor of landscape contracting

${ }^{3}$ Professor of vegetable crops.

${ }^{4}$ Postdoctoral at the High Tunnel Research and Education Center.

${ }^{5}$ Research support associate.

${ }^{6}$ Construction technician.
}

Hortlechnology • July-September 2002 12(3) tural production. The HTREF consists of 28 high tunnel research units that have dimensions of $17 \mathrm{ft}$ wide $\times 36$ $\mathrm{ft}$ long $\times 9 \mathrm{ft}$ high $(5.2 \times 11 \times 2.7 \mathrm{~m})$ and a support building located at the Horticulture Research Farm, Russell E. Larson Research Center, Rock Springs, Pa. Here research is being conducted to evaluate new designs for high tunnels and plastic coverings, cropping options, sequencing of vegetables and other horticultural crops, as well as production recommendations and budgets for crops grown in high tunnels.

The first eight tunnels were constructed using the design and system of crop production developed by Otho Wells and colleagues from the University of New Hampshire (Sciabarrasi and Wells, 1999; Wells, 1991, 1996, 2000; Wells and Loy, 1993). The New Hampshire design (Fig. 1) consisted of wood-framed end walls that were covered either with clear plastic film or exterior grade plywood. A door was framed into the end wall for general access in and out of the tunnel. To accomplish tillage operations in the tunnel, the end walls had to be removed. This required detaching the plastic and removing a series of screws. In addition, a continuous sheet of 4-year, greenhouse grade, clear plastic film was used to cover the entire tunnel, both the top and roll-up sides. The plastic was attached to a $1 \times 6$-inch $(2.5$ $\times 15.2-\mathrm{cm})$ hipboard, using two $1 \times 3$-inch $(2.5 \times$ $7.6-\mathrm{cm})$ boards that were attached to the hipboard.

Ifaproblem developed with the top covering or the roll-up sidewalls, or the covering needed to be replaced, all the screws fastening the $1 \times 3$-inch board had to be removed. This caused problems with the integrity of the screws and weathering of the boards due to a buildup of moisture under the plastic.

The objectives for developing a new high tunnel design were 1 ) to developed end walls that would afford quicker and more convenient access into the tunnels for performance of tillage and other operations associated with plasticulture systems and 2) to allow separate sheets of plastic to be used for the covering the top and sides of the high tunnel that would facilitate a quicker means of recovering a tunnel if a problem developed with either the plastic covering on the top or sidewalls.

\section{Details of construction using the Penn State high- tunnel design}

The pipe framing and assembly is the same for either the New Hampshire or the Penn State design. A general view of the Penn State high tunnel is presented in Fig. 2. A detailed list of components and prices used in construction of a $17 \times 36-\mathrm{ft}$ high tunnel using the Penn State design can be found in the

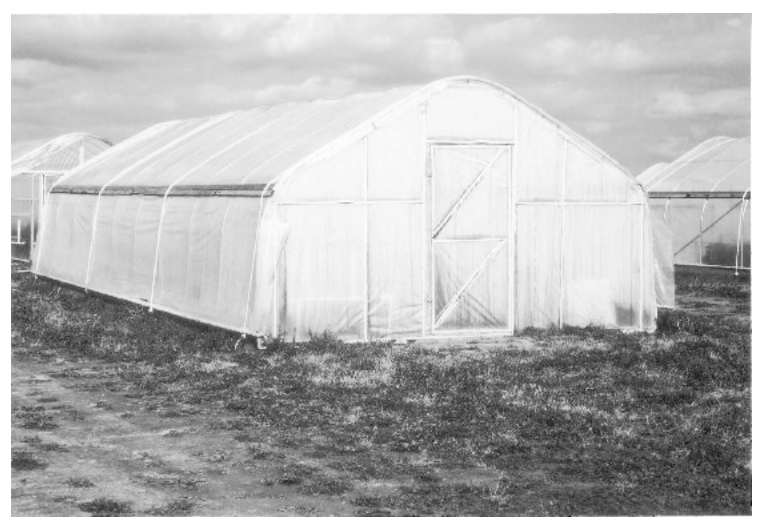

Fig. 1. High tunnel constructed using the New Hampshire design developed by Otho Wells, University of New Hampshire.

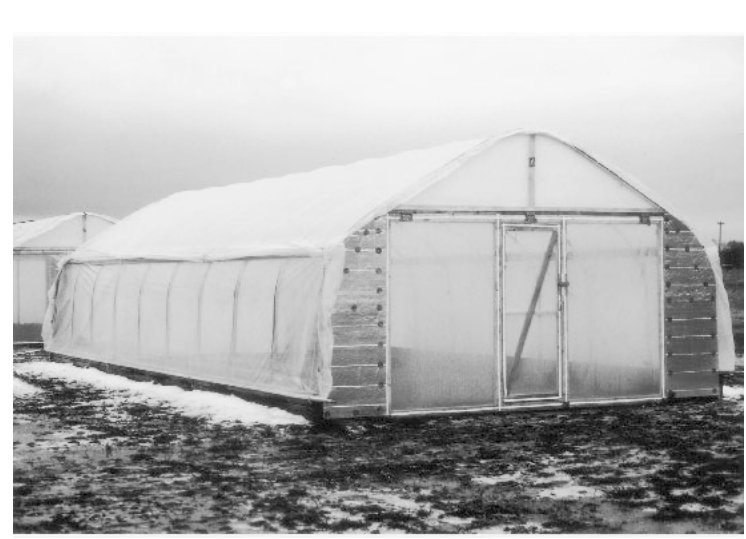

Fig. 2. High tunnel constructed using the Penn State design developed by researchers and extension specialists at the Penn State High Tunnel Research and Education Facility. 


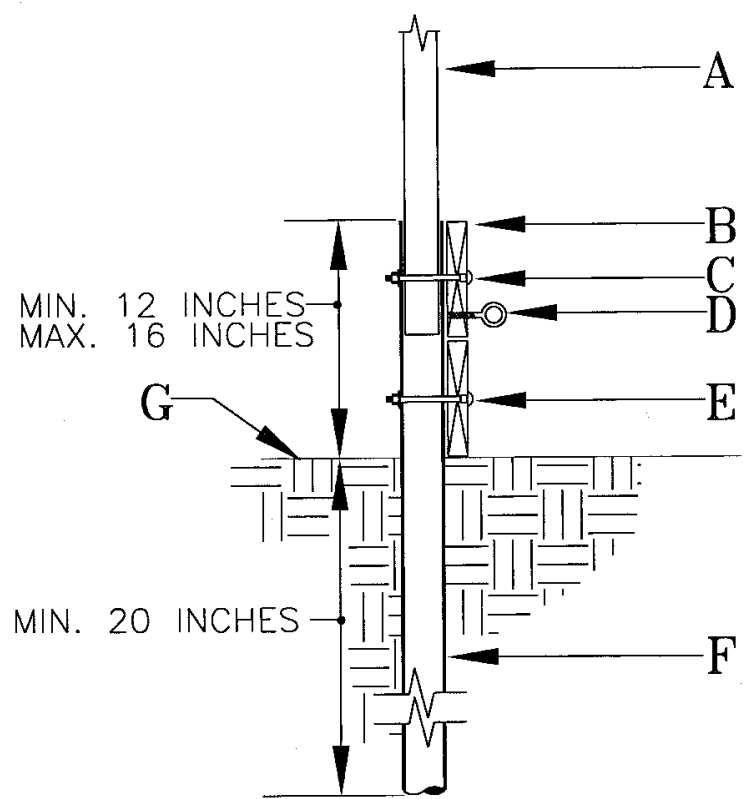

Fig. 3. Installation of the ground post and baseboard. (A) Hollow galvanized-steel bow. (B) Two pressure-treated wooden baseboards (reference Fig. 15G). (C) One $4.5 \times 0.25$-inch $(11.4 \times 0.6-\mathrm{cm})$ galvanized carriage bolt installed through pre-drilled holes in the ground post and bow. Materials are lined up with pre-drilled holes in the bow and ground post as supplied by the manufacturer before insertion of the bolt. (D) Galvanized eye screw for use in connection of the Arbor-Tie line. (E) One $4.5 \times 0.25$-inch galvanized carriage bolt installed through predrilled holes in the ground post and the baseboard. Pre-drilled holes supplied by the manufacturer are the only holes used when attaching the baseboards. (F) The manufacturer-supplied ground post should be installed to a recommended minimum depth of 20 inches $(50.8 \mathrm{~cm})$ below finished grade. There should be a minimum of 12 inches $(30.5 \mathrm{~cm})$ and a maximum of 16 inches $(40.7 \mathrm{~cm})$ remaining above finished grade for installation of the bow and baseboard. (G) Ground level or finished grade.

Penn State High Tunnel Manual (Lamont et al., 2001) available from the senior author. The manual also includes extensive environmental data as well as information on production of a wide variety of horticultural crops in the high tunnels. The price for the $17 \times 36-\mathrm{ft}$ high tunnel is about $\$ 1,900.00$, depending on prices of locally purchased materials.

\section{Construction steps}

The pipe frame kits were purchased from Ledgewood Farms (Moultonboro, N.H.). The high tunnel pipe frame kit $(17 \times 36 \mathrm{ft})$ consisted of ground posts, bows, purlins, roll-up sides kit, and nuts and bolts. The pipes used in the kit are made of galvanized steel tubing. The

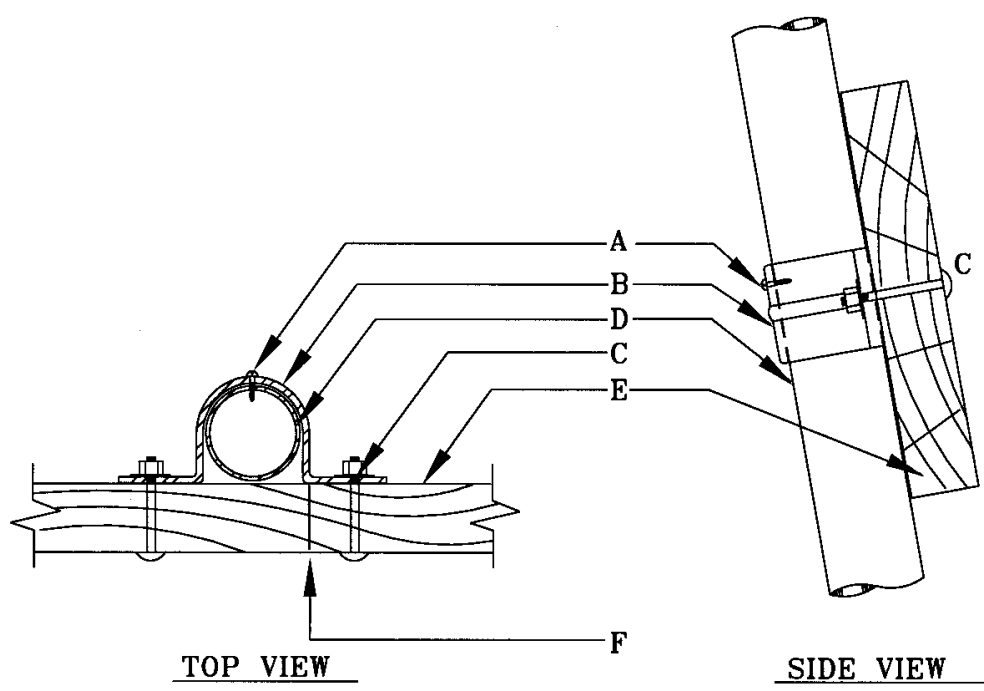

Fig. 4. Connection of the hip board to the steel bow. (A) Galvanized pan-head self-tapping set screw to keep the hip board in alignment on the bow. (B) Two-hole, standard-duty galvanized 1.25-inch $(3.2-\mathrm{cm})$ pipe-strap hanger. (C) Two $1.25 \times 0.375$-inch $(3.2 \times 1.0-\mathrm{cm})$ galvanized steel carriage bolts, nuts, and washers to connect the strap hanger to the hip board. (D) Hollow galvanized steel bow. (E) A $1.0 \times 4.0$-inch $(10.2 \times 2.54-\mathrm{cm})$ pressuretreated wooden hip board. (F) Hip boards are cut flush with the bows at the north and south ends of the greenhouse. A one-hole, standard-duty 1.25-inch galvanized pipe strap is used to connect the hip board to the bow.

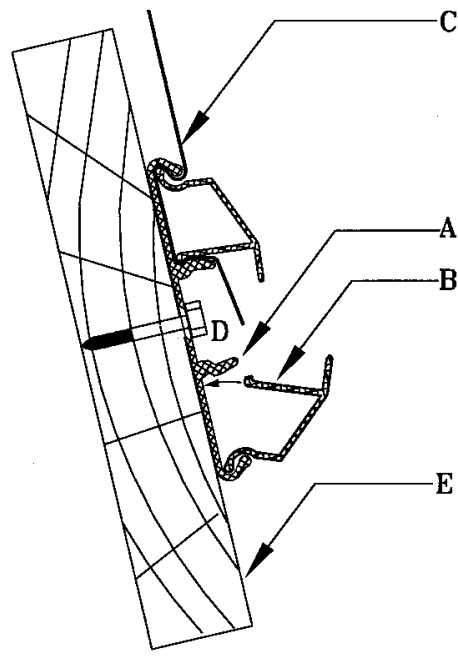

SIDE VIEW

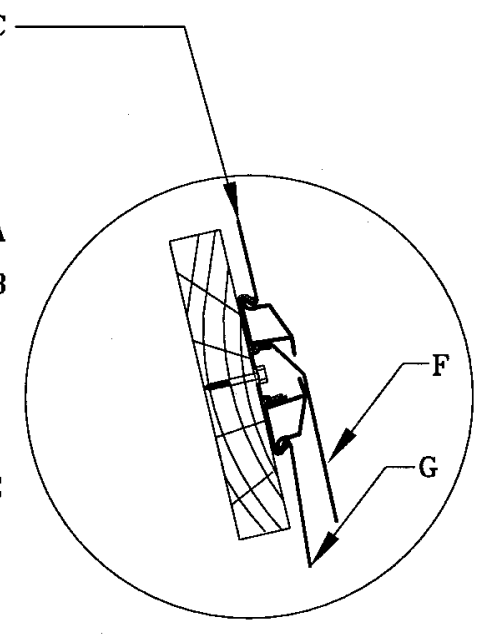

REDUCED SIDE VIEW ground posts are 13-gauge pipe with a 1.9-inch $(4.83-\mathrm{cm})$ outside diameter (OD), the bows are 14-gauge pipe with a 1.66 -inch $(4.2-\mathrm{cm})$ OD and the purlins and roll-up pipes are 15-gauge pipe with 1.32 -inch $(3.25-\mathrm{cm})$ OD. It is recommended that high tunnel kits with extended sides be purchased that allow the hipboard to be positioned higher on the bows and the roll-up sides to be raised higher for more efficient ventilation.

The ground posts are driven into the ground to a minimum depth of 20 inches $(50.8 \mathrm{~cm})$, and allowing suffi-
Fig. 5. Installation of the double-rail track to the hip board. (A) Surelock aluminum double-rail track. (B) Surelock preformed aluminum cap. (C) Plastic covering placed between the track and clamp. (D) A no. $10 \times$ 1 -inch $(2.5-\mathrm{cm})$ galvanized hex-head wood screws are used every $2 \mathrm{ft}(0.6$ $\mathrm{m})$, on center, to hold the rail to the hip board. (E) Hip board. (F) Plastic covering of the greenhouse trimmed so that a flap, even with the lower edge of the hip board, remains. (G) Plastic for the side panel roll-up wall locked in place with the lower clamp on the double aluminum track. 


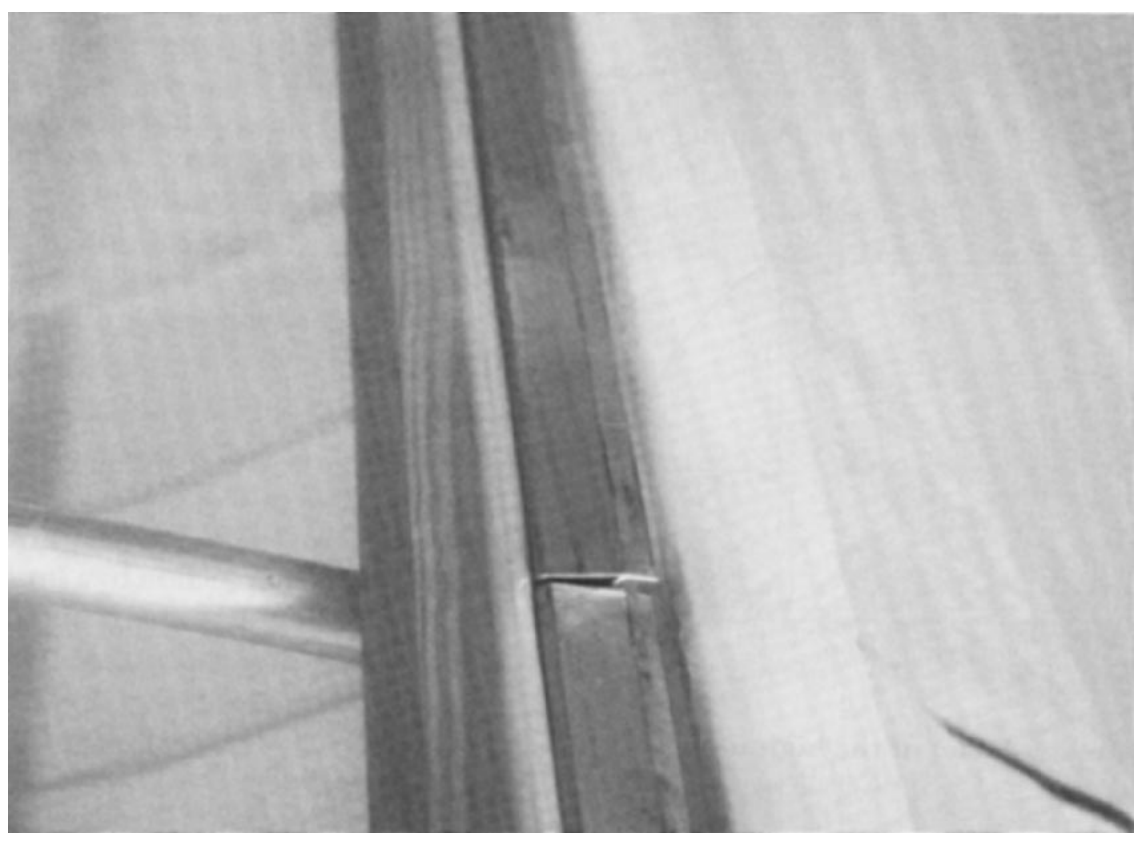

Fig. 6. Surelock aluminum double-rail track attached to the hipboard used to attach the plastic covering to the top and side of the high tunnel. Clip is being fastened to the lower track.

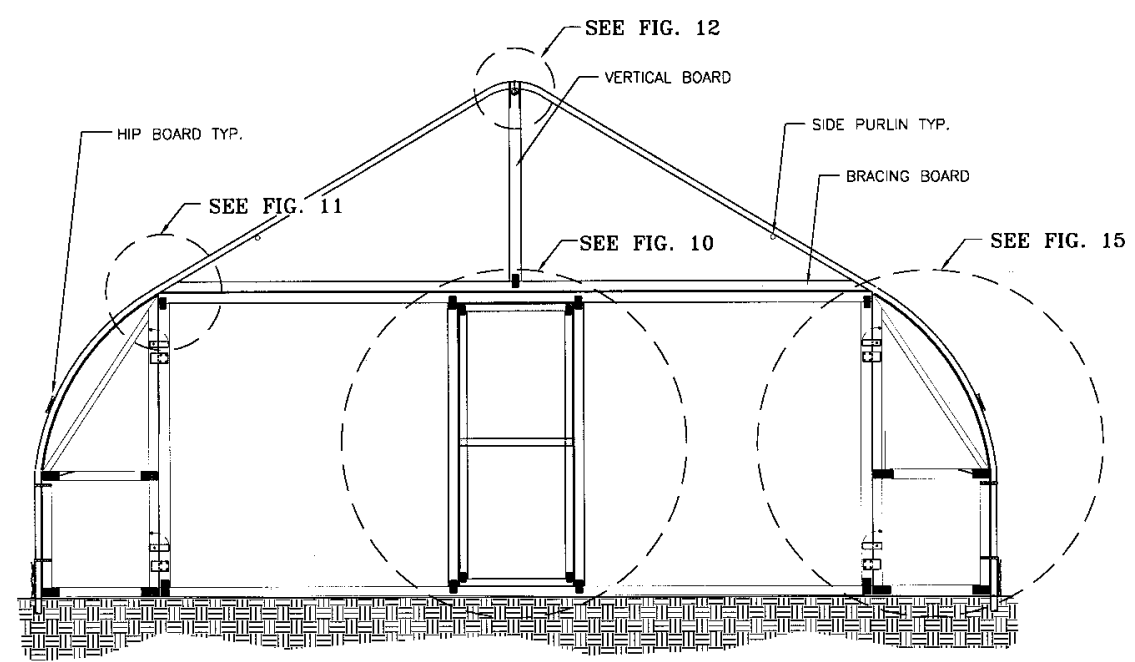

Fig. 7. The interior view of the front section or south end of the high tunnel.

cient length above the ground for attachment of the baseboard. Ground posts are placed on $4-\mathrm{ft}(1.2-\mathrm{m})$ centers. The bows are then assembled and the ends inserted into the ground post and secured using the appropriate hardware. The purlins (ridgepole and two side purlins) are then assembled and attached to the bows. The corner braces are attached to keep the tunnel from shifting out of upright position. The additional construction steps after the erection of the pipe frame are described below.

Step 1. Attach the baseboards (Fig. 3). The baseboards are pressuretreated $2 \times 6$-inch $\times 12-\mathrm{ft}(5 \times 15.2-\mathrm{cm}$ $\times 3.65-\mathrm{m})$ or $2 \times 12$-inch $\times 12-\mathrm{ft}(5 \times$ the bow and attach the hipboard with a 3 3/8-inch $(8.6-\mathrm{cm})$ bolt.

STEP 3. Using screws, attach 3.25inch $(9.5-\mathrm{cm})$ Surelock aluminum double rail track (Keeler-Glasgow Company, Hartford, Mich.) to the hipboard for securing the plastic cover and plastic for the sides (Fig. 5 and Fig. 6).

Step 4. Construct the upper endwalls with a bracing and a vertical board (Figs. 7, 8, and 9). Use a $2 \times 4$ inch $\times 12$-ft $(5 \times 10.2-\mathrm{cm} \times 3.6-\mathrm{m})$ board and taper the ends so that it will fit securely between the end bows as a bracing board, temporarily attaching it to the end bow to facilitate measurement of the vertical board. Take another $2 \times 4$-inch board (flat side out) and place it in the center of the bracing board. Measure and cut the vertical board so that it fits snug between the bracing board and center ridgepole purlin. This will require that the vertical board be notched to fit around the center ridgepole purlin. Secure the vertical board to bracing board with mending plates front and back (Fig. 10A, B, and $\mathrm{D}$ ). Place this frame (bracing and vertical board) in place and drill a hole on an angle up through the ends of the bracing board into the metal bow, securing it with a large self-tapping metal screw (Fig. 11E). Next take galvanized pipe strap and bring it over the top of the end bow and down to the bracing board using pan-head wood screws to secure the strapping tightly on both sides of the board (Fig. 11D). Next, take the galvanized pipe strap over the end bow and secure it to both sides of the vertical board, using pan-head wood screws (Fig. 12). The triangle section at the top of the endwalls can be covered with a variety of materials but in the Penn State design reported here it is covered with $3 / 8$-inch $(0.95-\mathrm{cm})$ exterior plywood (Figs. 7 and 8 ).

Step 5. Attach the aluminum single-track nursery lock (KeelerGlasgow Co.) over the end bows down to the hipboards (Fig. 12E). This is best accomplished by two people, one person holding the track on the bow while the second person drills holes through the track and the bow and fastens the track to the bow using self-taping screws.

Step 6. The next step is to build the lower end walls. The Penn State design allows for the center section of the end walls to be lifted up (Fig. 13) to accommodate the accessibility of a small four-wheel-drive, 2l-horsepower tractor with equipment. Equipment 


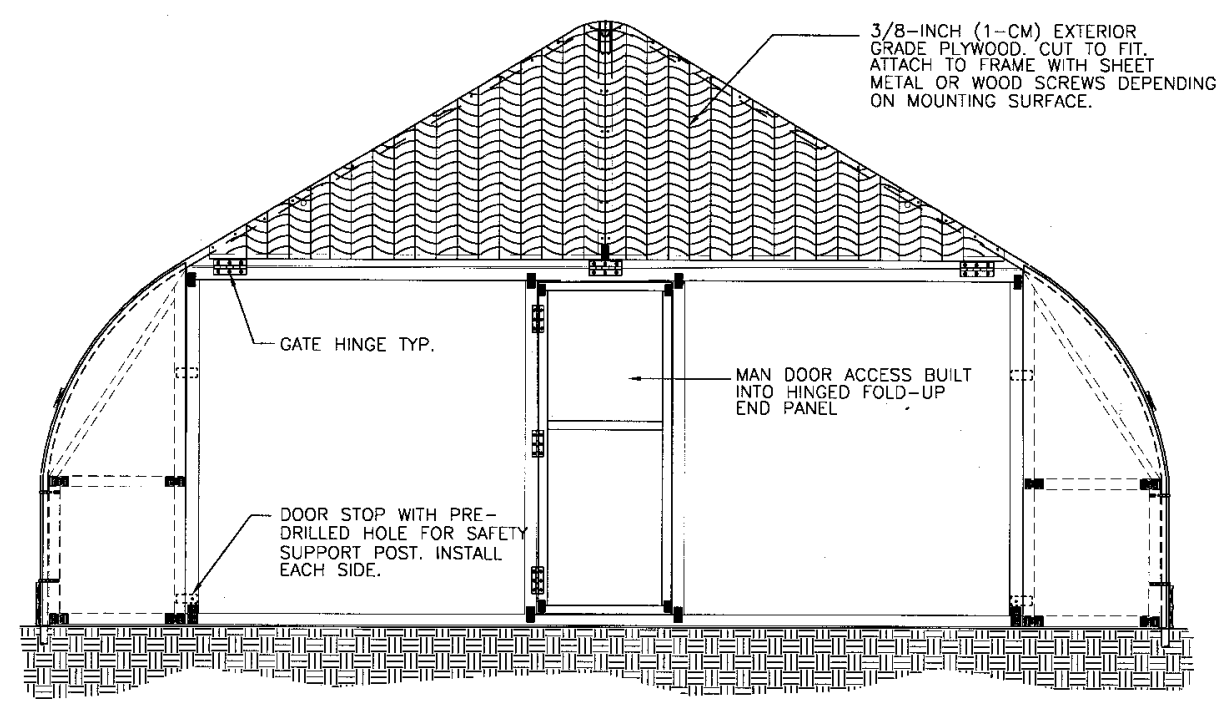

Fig. 8. The exterior view of the front section or south end of the high tunnel.

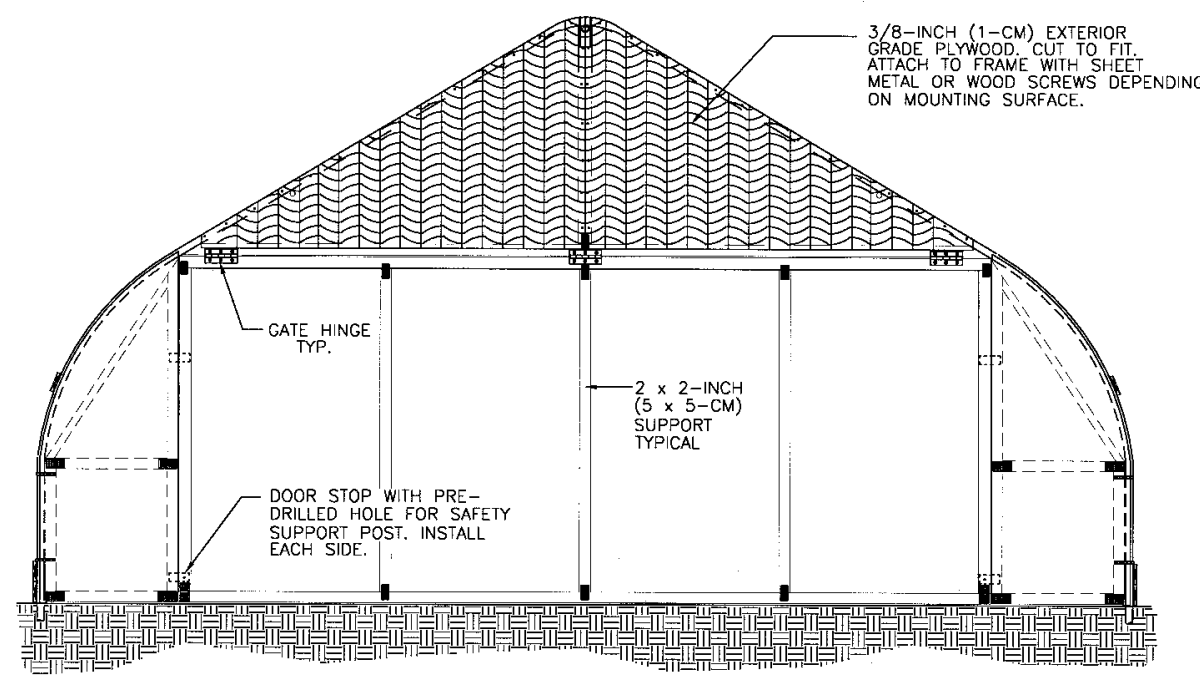

Fig. 9. The exterior view of the rear section or north end of the high tunnel.

includes a three-point hitch-mounted rototiller, that is used to prepare the soil and a small plastic mulch-drip irrigation tape applicator that is used to make raised plastic-mulch-covered beds with drip irrigation. The dimensions of the center section of lower end walls are $12 \mathrm{ft}$ wide by $8 \mathrm{ft}$ high $(3.6 \times$ $2.4 \mathrm{~m}$ ). The exterior frame of both sections is constructed of $2 \times 4$-inch lumber with all bottom boards pressure treated because of contact with soil and water. On the $17 \times 36-\mathrm{ft}$ research units there is an entrance door framed on the south end wall (Fig. 8). The north end wall uses $2 \times 2$-inch $(5$ $\mathrm{cm}$ ) lumber for internal support (Fig. 9 ). All the wood for the end walls is secured using mending plates on both sides. The end walls are best assembled on a firm, flat surface. It is recom- mended to attach the plastic on the end walls using batten tape and staples while they are flat on the ground. The end walls are attached to the overhead bracing board with three strong 3.5 -inch $(8.9-\mathrm{cm})$ galvanized gate hinges (Figs. 8 and 9). Details of the service door are presented in Fig. 10. In a commercial size high tunnel $[17 \times 96 \mathrm{ft}(5 \times 29 \mathrm{~m})]$ that a grower would purchase there would be a service door at each end. The center section of the lower endwall should be securely fastened when in the open position. The authors use $2 \times 2$ inch posts with metal dowels at each end. One end of the post is placed in the soil and the upper dowel is placed through a pre-drilled hole in the door stop (Fig. 8). The upper metal dowel should extend above the doorstop by several inches.
Step 7. On either side of the center section are two hinged end panels (Figs. 14 and 15). These are constructed of $2 \times 4$-inch lumber frames that have a pressure-treated base piece and are attached to the side bows by heavy metal pallet strapping. They can be covered with a variety of materials. In the original stages of development aluminum-covered Styrofoam insulating material was used but now 3/8-inch exterior plywood is being used. Whatever material is chosen, it is cut to the outline of the bow and overlaps the edge of the center section (Fig. 14). It is held against the edge of the center section by a small piece of wood that rotates on the inside of the end panel (Fig. 15J).

Step 8. The next step is to cover the top of the high tunnel. The plastic used for covering the high tunnels is 3or 4-year life, greenhouse-grade 6-mil $[0.006$-inch $(144-\mu \mathrm{m})]$ plastic. It helps to have a crew of six people and a day with wind less than 5 miles/h $(8.0$ $\mathrm{km} \cdot \mathrm{h}^{-1}$ ) to facilitate covering the tunnel. Snap-on clips attach the top piece of plastic to the single aluminum rail on the end bows. The top track of the double aluminum track attached to the hipboard makes the covering or recovering of the tunnels easier than the New Hampshire design. The rollup sidepieces of plastic are 6.5-ft (2.0$\mathrm{m}$ ) wide and are clipped into place on the lower track of the double track (Fig. 5B). The lower end of the roll-up side is then attached to the roll-up pipe by plastic clips at every bow, while the pipe is lying on the ground. Trim excess plastic [suggest 8-inch (20.3$\mathrm{cm}$ ) overhang] for sidewalls (Fig. 5). The plastic can then be rolled up on the pipe (Fig. 16). Where the sections of roll-up pipe slide in to one another it is recommended to put two small machine screws, one on each side, so the pipes cannot rotate.

Step 9. The next step is to attach four eyescrews on upper portion of the baseboard; one at each end and two spaced equally apart between the ends (Fig. 3D). AborTie, a soft polypropylene material, (Ben Meadows Company, Janesville, Wis.) is placed over the tunnel and attach at the eight eyescrews. This will prevent the top cover and sides from flapping in the wind.

STEP 10. Each tunnel will need its own water supply and fertilizer injection unit. Any piping to service the units should be in a location where tilling operations will not damage the lines. 
There are different options on constructing a fertilizer injection system (fertigation) and water supply system to the tunnels. The one used in the Penn State High Tunnels consists of an 11 $\mathrm{gal} / \mathrm{min}\left(41.6-\mathrm{L} \cdot \mathrm{min}^{-1}\right)$ Dosatron (Dosatron International, Clearwater, Fla.) unit for fertigation, a preset pressure regulator and a screen filter. It is convenient to have a spigot in each

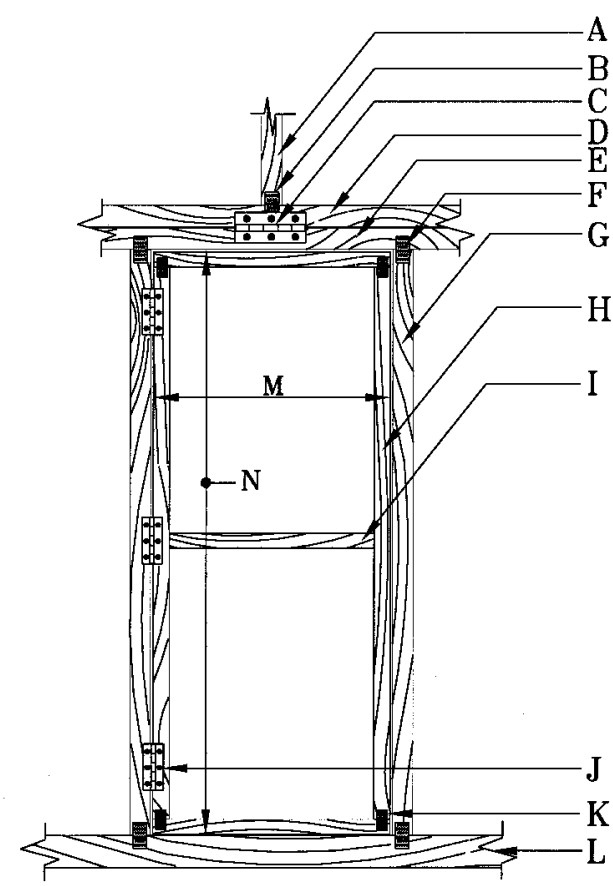

Fig. 10 Construction of the main entrance door. (A) A $2 \times 4$-inch $(5 \times$ $10.2-\mathrm{cm})$ vertical support from the bow to the bracing board. (B) A $3 \times$ 5 -inch $(7.6 \times 12.7-\mathrm{cm})$ galvanized mending plate, both front and back. (C) A 3.5-inch $(8.9-\mathrm{cm})$ galvanized gate hinge installed on the bracing board and upper support for the flipup door. (D) A $2 \times 4$-inch $\times 12$-ft ( $5 \times$ 10.2-cm $\times 3.6-\mathrm{m})$ bracing board. $(\mathrm{E})$ $2 \times 4$-inch $\times 12$-ft upper support for flip-up door. (F) A $3 \times 5$-inch galvanized mending plate located at top and bottom of vertical door supports, both front and back. (G) A $2 \times 4 \times 77$-inch $(5 \times 10.2 \times 195.6-\mathrm{cm})$ vertical door support. (H) A $2 \times 2$ inch (5-cm) door framing. (I) A $2 \times$ 2 -inch cross support for door frame. (J) A $2 \times 3$-inch $(5 \times 7.6$-cm $)$ galvanized entrance door hinge, three per door equally spaced. (K) A $2 \times 4$-inch galvanized mending plate located at each doorframe corner, both front and back. (L) A $2 \times 4$-inch $\times 12$-ft lower support for flip-up door, pressure-treated lumber. (M) Suggested dimension 28 inches (71.1 cm). (N) Suggested dimension 77 inches $(195.6 \mathrm{~cm})$. tunnel for water to fill the stock fertilizer containers (Fig. 17). This allows for the precise watering of crops using drip irrigation and the ability to add additional fertilizer as needed to crops especially, in double cropping situations on plastic mulch.

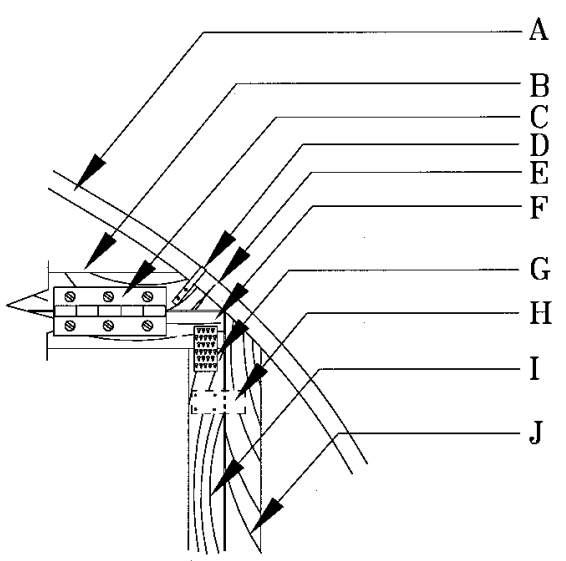

Fig. 11. Connection of the upper end wall to the end bow. (A) Hollow galvanized steel end bow. (B) A $2 \times 4$ inch $\times 12$-ft $(5 \times 10.2-\mathrm{cm} \times 3.6-\mathrm{m})$ bracing board of finished lumber is used as a fixed support for the flip-up end panel. Both ends taper cut so that the board will fit snugly against the bow and parallel to the ground. Bottom dimension on the board should be $12 \mathrm{ft}(3.6 \mathrm{~m})$. (C) A 3.5inch $(8.9-\mathrm{cm})$ galvanized gate hinge installed on bracing board and upper support for flip-up end panel. (D) Steel pipe hanger strapping used to secure the wooden support to the end bow. Galvanized pan-head wood screws with washers used to secure the strap to the wood. (E) Wooden support is also attached to the bow with a self-tapping sheet-metal screw countersunk 0.5 inches $(1.3 \mathrm{~cm})$ below the surface of the wooden support. Screw hole is located no closer than 2.5 inches $(6.4 \mathrm{~cm})$ to either end of the board. (F) Upper support of $2 \times 4$-inch $\times 12$-ft finished lumber. (G) A $3 \times 5$-inch $(7.6 \times 12.7$ cm) galvanized mending plates used front and back to secure corners of panel. (H) Panel stop constructed of 1 $\times 4 \times 7$-inch $(2.5 \times 10.2 \times 17.8$-cm $)$ finished lumber and attached to the inside of the panel with $4 \# 8 \times 2.5$ inch $(6.3-\mathrm{cm})$ flat-head galvanized wood screws. Two stops, one top and one bottom, mounted on each side of the panel. (I) A $2 \times 4 \times 77$-inch $(5 \times$ $10.2 \times 195-\mathrm{cm})$ side support made of finished lumber for flip-up panel. (J) A $2 \times 4$-inch $(5 \times 10.2-\mathrm{cm})$ side support of finished lumber for the hinged side panel.

\section{Conclusions}

The Penn State high tunnel design demonstrates that the improvements described allow for greater ease of access for equipment operations and periodic replacement of plastic than previously designed systems.

The Penn State high tunnel design of the end walls allows easy access for small power tillage equipment to the inside of the high tunnel for preparation of the soil and other operations associated with the use of plasticulture. It is a very quick operation to open the hinged end panels and lift up the center section of the end walls.

The change made to the way the plastic is attached to the hipboard allows for easy removal of either the plastic covering the top or the side walls, if a problem develops, or the covering needs to be changed due to age or a grower wishes to use different covering or materials such as insect screen on the side walls. The aluminum track system with clips is more convenient to work with

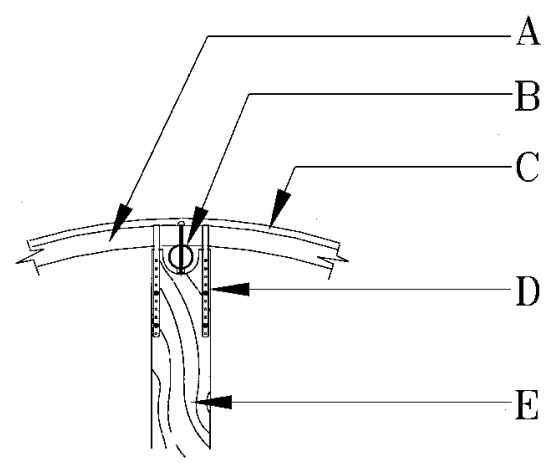

Fig. 12. Attachment of the upper end-panel wall to the center ridge pole purlin/end bow. (A) Hollow galvanized steel end bow. (B) Center ridge pole purlin attached to bow with hardware kit supplied by manufacturer. (C) Single-track aluminum nursery lock channel mounted on the crest of the bow with sheet-metal screws. (D) Galvanized pipe strap used to attach the vertical support to the end bow with no. $8 \times$ 1.25-inch $(3.2-\mathrm{cm})$ galvanized panhead screws and washers. One strap mounted on each side of the center purlin and fastened both front and back Straps installed before the lock channel. (E) A $2 \times 4$-inch $(5 \times 10.2$ cm) vertical support for the lower bracing board. The center of the board is custom cut to accommodate the ridge purlin before installation. The upper end of the board should rest snugly against the under side of the bow. 


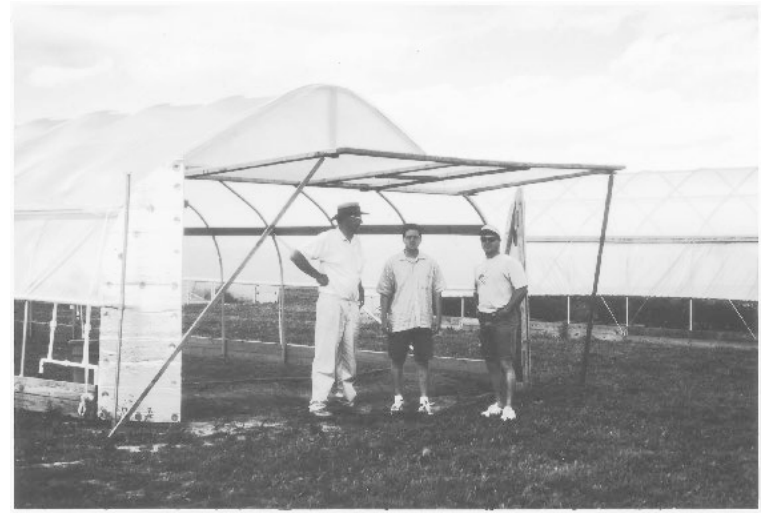

Fig. 13. Center section of lower portion of the end walls used in the Penn State high tunnel design opened up to allow easy entrance and exit of machinery.

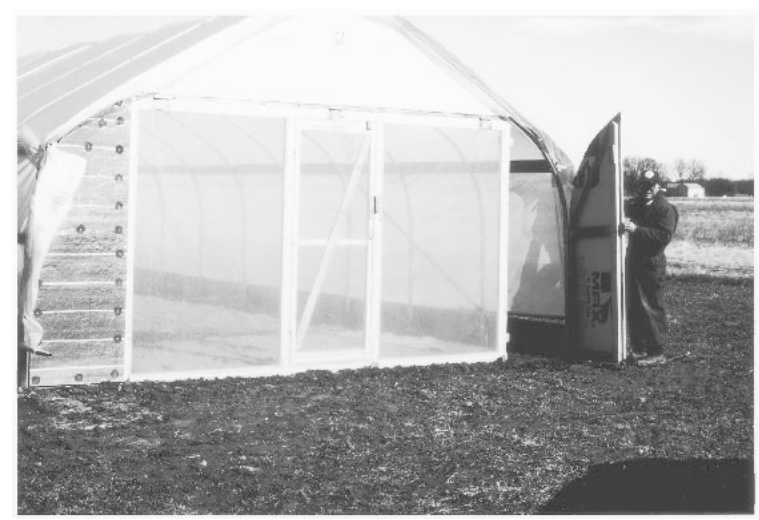

Fig. 14. Side panel opened up before raising the center section in the Penn State high tunnel design.

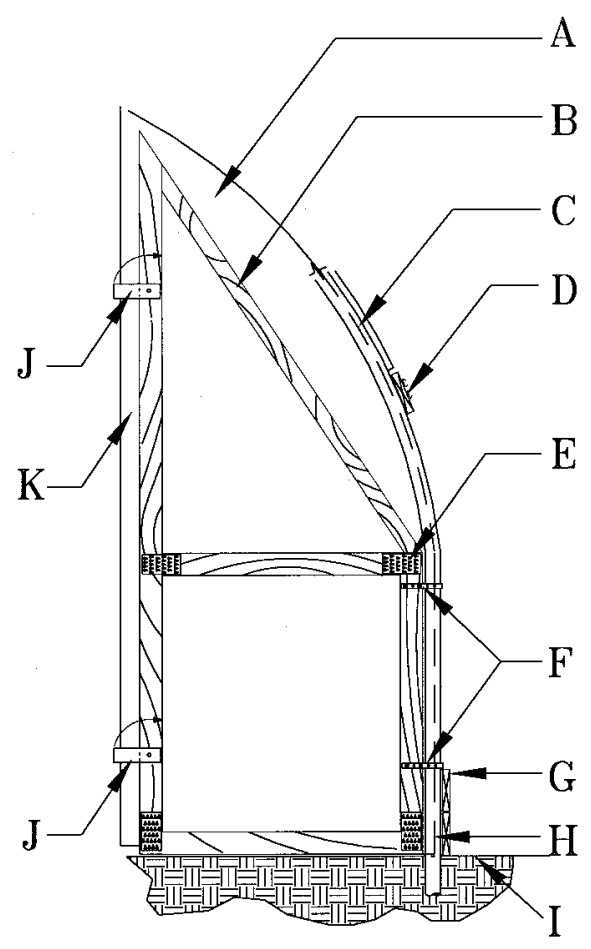

Fig. 15. Detail of the hinged end panel as seen from the interior of the high tunnel. (A) A 0.375-inch (1-cm) exterior-grade plywood panel cut to the curvature of the bow and then attached to the panel frame. (B) A 2 $\times 2$-inch $(5-\mathrm{cm})$ wooden bracing attached to the panel frame with galvanized wood screws. (C) Galvanized steel end bow with single track aluminum nursery lock channel. The nursery lock channel is mounted on the crest of the bow with sheet metal screws. (D) Pressure treated $1 \times 4$ inch $(2.5 \times 10.2-\mathrm{cm})$ wooden hip board with double rail track (reference Fig. 4). (E) A $3 \times 5$-inch $(7.6 \times$ $12.7-\mathrm{cm})$ galvanized mending plate mounted both front and back. (F) A 0.75 -inch $(1.9-\mathrm{cm})$ wide, heavy-duty pallet strap attached to wooden frame with galvanized wood screws. Two screws used per side to attach the strap to the wood. (G) Pressuretreated wooden baseboard (reference Fig. 3). (H) Metal galvanized ground post (reference Fig. 3). (I) Finished ground level. (J) Rotating wooden stop constructed of $1 \times 4 \times 7$-inch $(2.5 \times 10.2 \times 17.8-\mathrm{cm})$ finished lumber. Stop attached to panel frame with one wood screw to allow stop to rotate to upright position and allow panel to swing out. (K) A 2-inch (5cm) overlap between edge of plywood facing and end panel wooden bracing. 


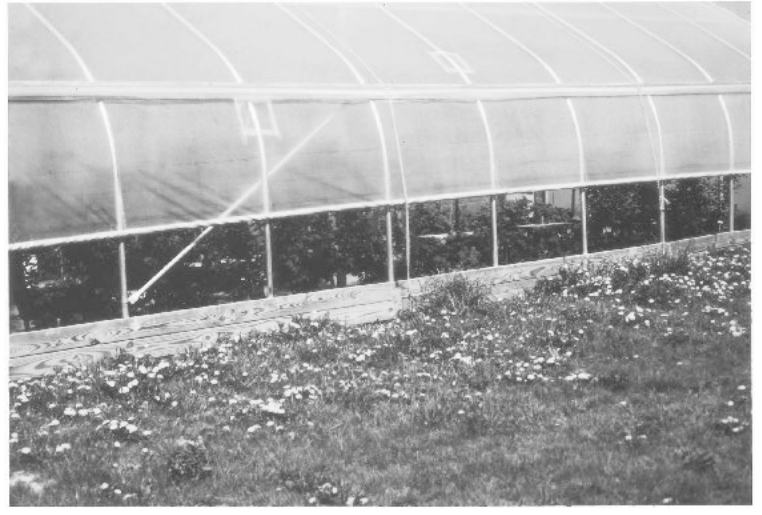

Fig. 17. Configuration of the fertilizer injector. (A) Water inlet connection point using a quikconnect adaptor or regular female hose connection. (B) A 0.75-inch (1.9-cm) interior diameter (ID) schedule-40 polyvinyl chloride (PVC) pipe, typical. (C) Mounting bracket as provided by the manufacturer for the fertilizer injector. (D) Fertilizer injector (FI). (E) Threaded pipe union located on each side of the FI to facilitate installation and removal of the injector. (F) A 0.75-inch ID 90 PVC pipe elbow. (G) Straight PVC ball valve located on each side of the FI. During normal operations the valve position is open. (H) A 0.75inch ID PVC tee. (I) In-line screen filter unit with minimum 150 mesh. (J) Pressure regulator with adjustments from 0.5 to $5 \mathrm{gal} / \mathrm{min}\left(18.9 \mathrm{~L} \cdot \mathrm{min}^{-1}\right)$ with water pressure of $10 \mathrm{lb} / \mathrm{inch}^{2}(69 \mathrm{kPa})$. (K) Water outlet connection point using a quikconnect adaptor or male hose connection. (L) Vacuum feed line from fertilizer tank to FI. (M) A 0.75-inch-ID straight PVC ball valve for use in bypassing FI. During normal operations the valve position is closed. (N) Inlet fitting with fine screen cover connected to feed line. $(\mathrm{O})$ Liquid fertilizer mixed in movable container. (P) Ground level or finished grade. (Q) Pressure-treated $1 \times 4$-inch $(2.5$ $\times 10.2-\mathrm{cm})$ board mounted between two bows.

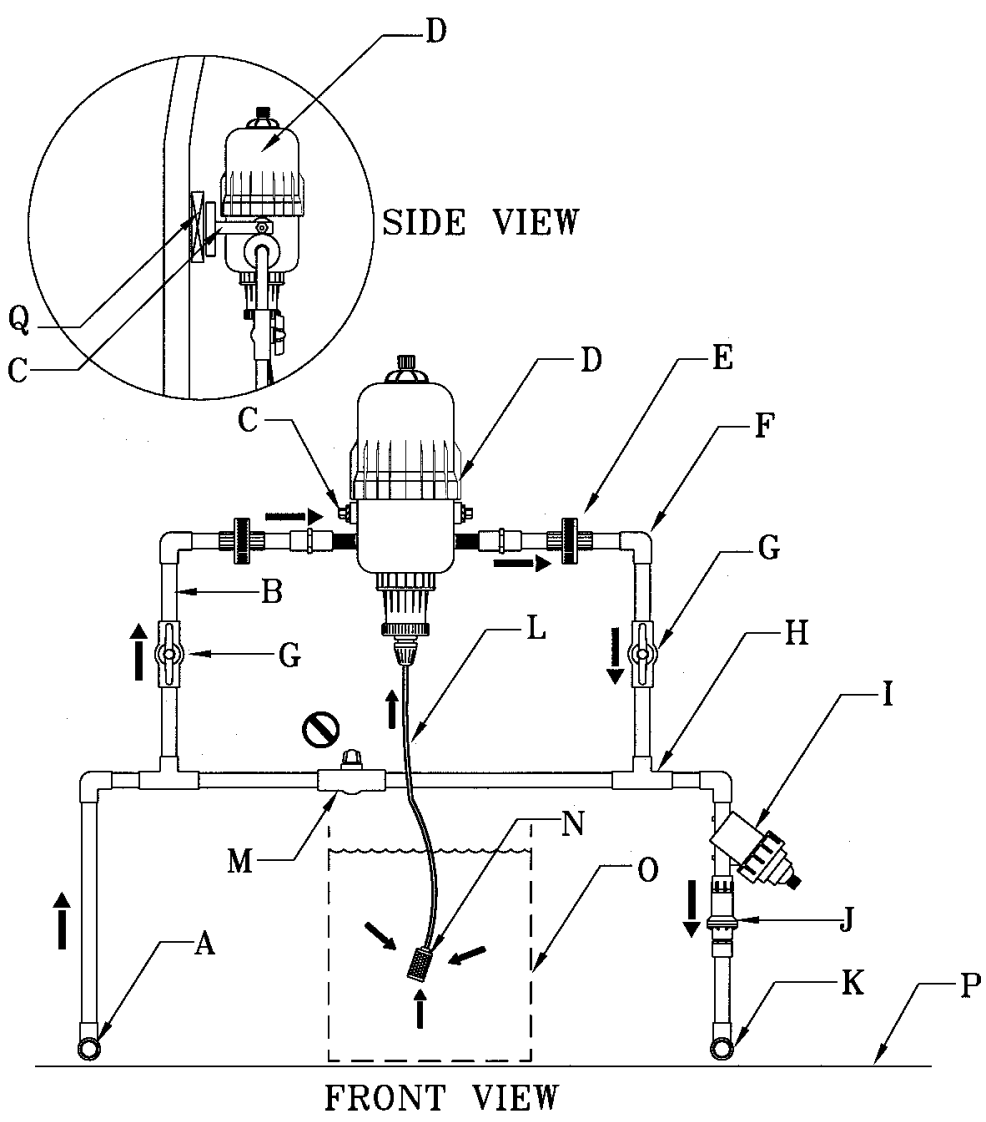

Fig. 16. Plastic sides are rolled up to provide ventilation of the high tunnel.
White, B. Dye, and E. Burkhart. 2001. The Penn State high tunnel research and education facility manual. Pa. State Coop. Ext. Pub. CP02-2.

Sciabarrasi, M. and O.S. Wells. 1999. Guidelines for using high tunnels for tomato production. Univ. N.H.Coop. Ext. Fact Sheet 2 .

Wells, O.S. 1991. High tunnels shelter early crops. Amer. Veg. Grower 39(2):44,4647.

Wells, O.S. and J. B. Loy. 1993. Rowcovers and high tunnels enhance crop production in the Northeastern United States. HortTechnology 3(1):92-95.

Wells, O.S. 1996. Rowcover and high tunnel growing systems in the United States. HortTechnology 6:172-176.

Wells, O.S. 2000. Season extension technology. Proc. $15^{\text {th }}$ Intl. Congr. Plastics in Agr. and the $29^{\text {th }}$ Natl. Agr. Plastics Congr. Appendix B, p. 1-7.

Wodecki, M., W.J. Lamont, and M.D. Orzolek. 2001. Penn State Center for Plasticulture. 10 Mar. 2002. <http:// plasticulture.cas.psu.edu>. 